\title{
New Derivative Spectrophotometric Methods for the Determination of Fluoxetine - An Antidepressant Drug
}

\author{
M. MATHRUSRI ANNAPURNA* and DEBI PRASAD PRADHAN \\ *Department of Pharmaceutical Analysis and Quality Assurance, \\ GITAM Institute of Pharmacy, GITAM University, Visakhaptanam, India \\ Department of Pharmaceutical Analysis and Quality Assurance, \\ Roland Institute of Pharmaceutical Sciences, Berhampur-760010, Orissa, India \\ mathrusri2000@yahoo.com
}

Received 2 June 2012 / Accepted 21 June 2012

\begin{abstract}
Fluoxetine is an antidepressant of the selective serotonin reuptake inhibitor class. Two simple, rapid and sensitive first and second derivative spectrophotometric methods are developed for the determination of fluoxetine (FLX) in pharmaceutical dosage forms (capsules). The absorption minima was chosen (at $235 \mathrm{~nm}$ ) in first order (Method A) and amplitude (229-238.5 nm) was selected in second order derivative spectral calculations. Fluoxetine follows Beer's law in the concentration range of $1-60 \mu \mathrm{g} \mathrm{mL} L^{-1}\left(\mathrm{r}^{2}=0.999\right)$ in first order as well as in second order $\left(\mathrm{r}^{2}=0.9994\right)$ derivative spectroscopy respectively. The proposed methods can be successfully applied for the determination of Fluoxetine in commercial brands of pharmaceutical formulations. No interferences were observed from the common excipients in the formulations. The methods were validated according to $\mathrm{ICH}$ guidelines.
\end{abstract}

Keywords: Fluoxetine $\mathrm{HCl}$, Derivative spectrophotometry, Antidepressant drug

\section{Introduction}

Fluoxetine $^{1} \mathrm{HCl}$ (FLX) chemically, $N$-methly-3-phenyl-3-[4-(trifluoromethyl) phenoxy] propan-1-amine. It is available as white crystals with molecular weight $309.33 \mathrm{~g} / \mathrm{mol}$ with molecular formula, $\mathrm{C}_{17} \mathrm{H}_{18} \mathrm{~F}_{3} \mathrm{NO}$ (Figure 1). It is an antidepressant of the selective serotonin reuptake inhibitor class; it is approved for the treatment of major depression, obsessive compulsive disorder, anorexia nervosa, panic disorder, bulimia nervosa and premenstrual dysphonic behavior. The literature survey reveals that spectrophotometric and fluorimetric methods $^{2-4}$ and liquid chromatographic ${ }^{5-6}$ methods were developed. Mandrioli ${ }^{7}$ et al developed spectrofluorimetric and capillary zone electrophoretic methods for the determination if FLX. Further Souverain ${ }^{8}$ et al., analysed fluoxetine and its metabolites in plasma by LC/MS with column-switching approach and in the present work two new spectrophotometric methods were developed for the estimation of Fluoxetine in capsules and validated as per the ICH guidelines ${ }^{9}$. 
<smiles>CNCC[C@H](Oc1ccc(C(F)(F)F)cc1)c1ccccc1</smiles>

\section{Experimental}

Figure 1. Chemical structure of fluoxetine

A double beam UV-VIS spectrophotometer (UV-1800, Shimadzu, Japan) connected to computer loaded with spectra manager software UV Probe was employed with spectral bandwidth of $1 \mathrm{~nm}$ and wavelength accuracy of $\pm 0.3 \mathrm{~nm}$ with a pair of $10 \mathrm{~mm}$ matched quartz cells. All weights were taken on electronic balance (Denver, Germany).

\section{Chemicals and reagents}

Analytical grade Methanol (Merck) was purchased. Fluoxetine (FLX) was obtained from Sun Pharma Ltd. (India) and was used as such without further purification.

\section{Recommended procedure and calibration curve}

\section{Preparation of stock solution}

The standard solution of fluoxetine was prepared by dissolving accurately weighed $25 \mathrm{mg}$ of the drug was dissolved in methanol in a $25 \mathrm{~mL}$ volumetric flask and diluted with methanol to obtain a working standard solution $\left(100 \mu \mathrm{g} \mathrm{mL} \mathrm{L}^{-1}\right)$.

First-order derivative spectrometry (Method A)

The drug solution was scanned $(200-400 \mathrm{~nm})$ against reagent blank and the absorption spectrum was recorded. This spectrum was derivatised to get first order derivative spectra (Figure 2) and the zero crossing point was found to be at $227 \mathrm{~nm}$.

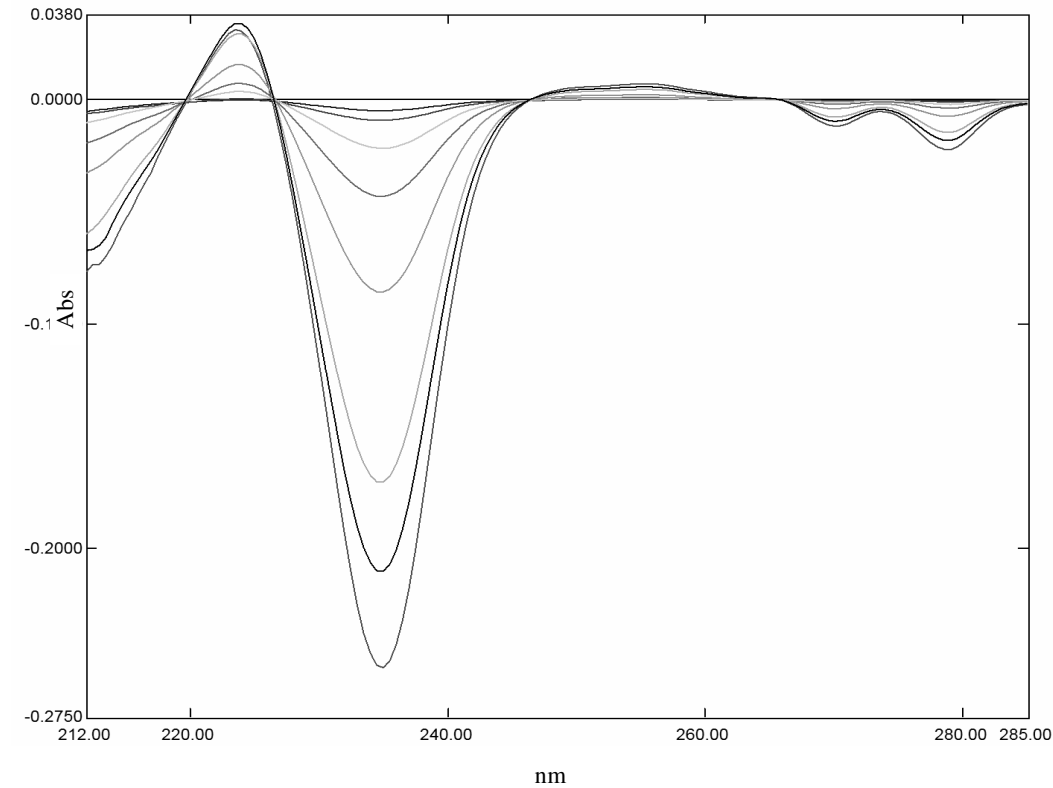

Figure 2. First derivative overlay spectrum $\left(D_{1}\right)$ of Fluoxetine 
A series of solutions (1-60 $\left.\mu \mathrm{g} \mathrm{mL}^{-1}\right)$ were prepared, scanned against reagent blank and their of the corresponding troughs (or minima) were measured at $235.0 \mathrm{~nm}$ and plotted against the concentration (Figure 3 ).

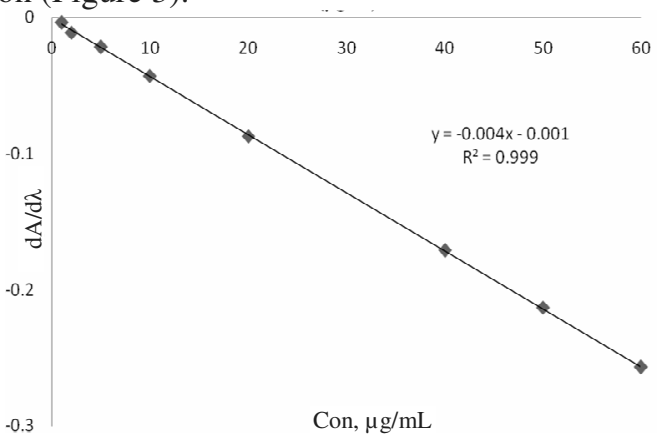

Figure 3. Calibration curve of Fluoxetine (Method A)

Second-order derivative spectrometry (Method B)

The drug solution was scanned $(200-400 \mathrm{~nm})$ against reagent blank and the absorption spectrum was recorded and was derivatised to get second order derivative spectra (Figure 4). This spectrum shows minima $(229 \mathrm{~nm})$ as well as maxima $(238.5 \mathrm{~nm})$ and therefore the amplitude was chosen for the analytical determinations.

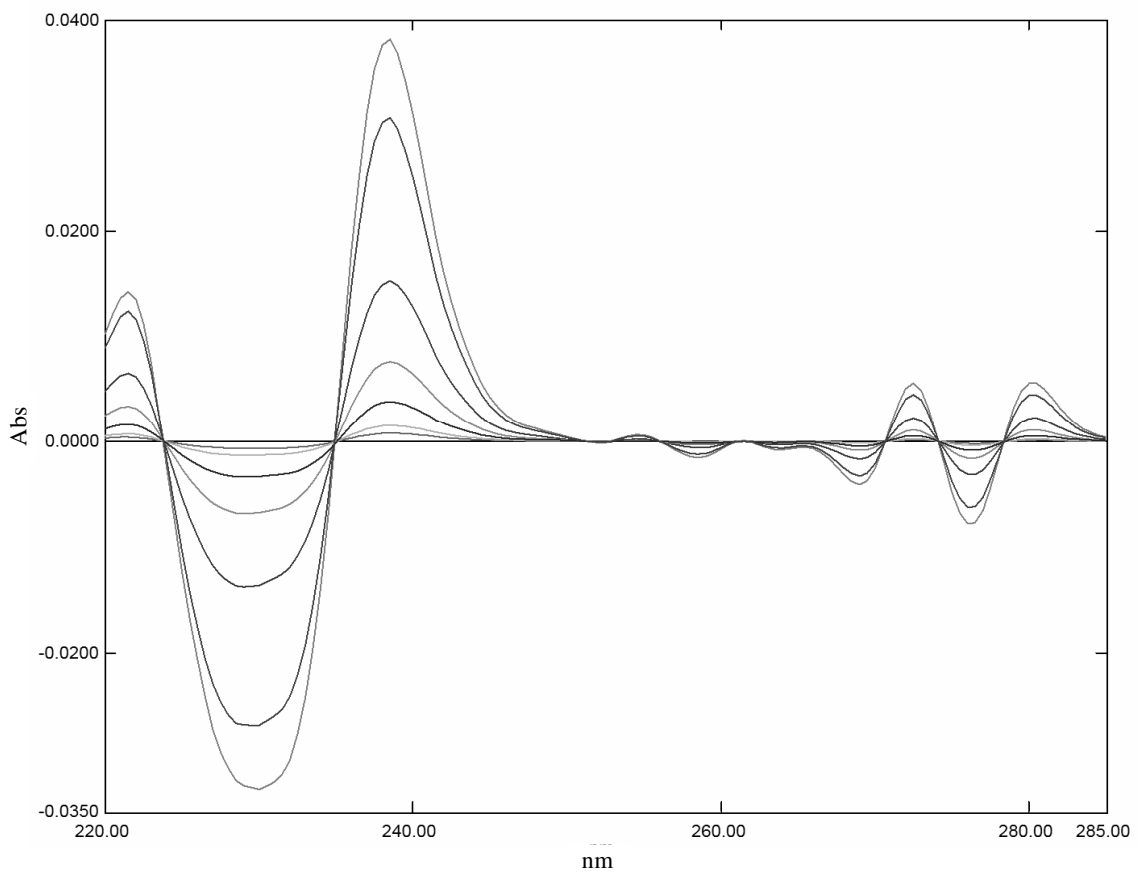

Figure 4. Second derivative overlay spectrum $\left(D_{2}\right)$ of Fluoxetine

A series of solutions (1-60 $\mu \mathrm{g} \mathrm{mL}^{-1}$ ) were prepared, scanned against reagent blank and their amplitude was measured. A graph was plotted by taking the concentration on the $x$-axis and the corresponding amplitude values on $y$-axis (Figure 5). 


\section{Assay procedure for the commercial formulations (Capsules)}

Fluoxetine is available as capsules in local market with brand names DAWNEX $(20 \mathrm{mg}$, Micro labs), FLUDAC (10, 20 and $60 \mathrm{mg}$, Cadila Pharma), FLUNIL ((10, 20 and $60 \mathrm{mg}$, Intas) and PRODEP ((10, 20 and $60 \mathrm{mg}$, Sun Pharma) and are procured from the medical store.

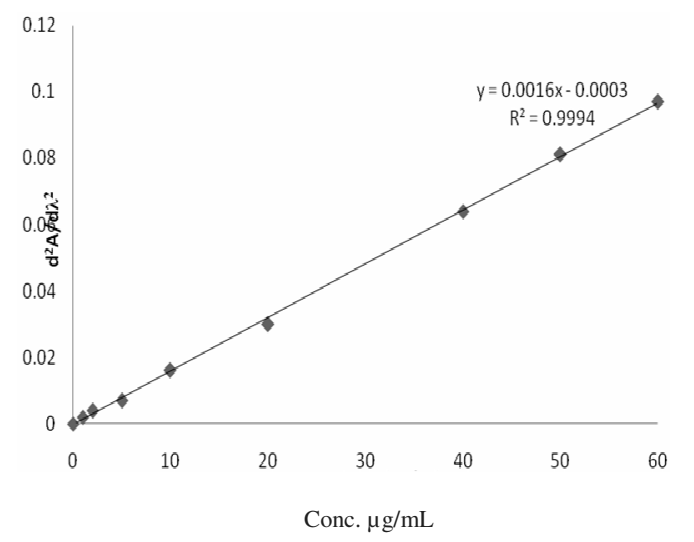

Figure 5. Calibration curve of Fluoxetine (Method B)

20 Capsules were taken from three different brands and the FLX equivalent to $25 \mathrm{mg}$ was weighed from each brand and extracted with methanol, sonicated and make up to volume with methanol in three separate $25 \mathrm{~mL}$ volumetric flasks $(1 \mathrm{mg} / \mathrm{mL})$ and filtered. The dilutions were made from this stock with methanol as per the requirement. A series of solutions $(1.0-60.0 \mu \mathrm{g} / \mathrm{mL})$ were prepared, scanned and the corresponding values were recorded and calibration curves were drawn. A straight line was obtained and the results obtained were shown in Table 1.

Table 1. Assay of commercial formulations

\begin{tabular}{cccccccc}
\hline \multirow{2}{*}{ Brand } & $\begin{array}{c}\text { Labelled } \\
\text { Amount, mg }\end{array}$ & \multicolumn{2}{c}{$\begin{array}{c}\text { Amount } \\
\text { Obtained, mg } \\
\text { Method }\end{array}$} & \multicolumn{2}{c}{$\begin{array}{c}\text { \% Recovery } \\
\text { Method }\end{array}$} & \multicolumn{2}{c}{$\begin{array}{c}\text { \% RDD } \\
\text { Method }\end{array}$} \\
\cline { 3 - 8 } & & $\mathrm{A}$ & $\mathrm{B}$ & $\mathrm{A}$ & $\mathrm{B}$ & $\mathrm{A}$ & $\mathrm{B}$ \\
\hline I & 20 & 19.967 & 19.786 & 99.835 & 98.931 & 0.8673 & 0.6578 \\
II & 20 & 19.865 & 19.564 & 99.325 & 97.822 & 0.9876 & 0.8741 \\
III & 20 & 19.891 & 19.831 & 99.455 & 99.155 & 1.3421 & 0.8321 \\
\hline
\end{tabular}

*Each value is average of three determinations

\section{Precision and accuracy}

The precision study was done by recording the response of six replicates in Method A $(20 \mu \mathrm{g} / \mathrm{mL})$ and Method B $(40 \mu \mathrm{g} / \mathrm{mL})$ and the \%RSD was calculated. Accuracy was evaluated by the percent recovery studies by the addition of $80 \%, 100 \%$ and $120 \%$ of pure sample solution to the pre-analysed formulation solution. For the present study $20 \mu \mathrm{g} / \mathrm{mL}$ of FLX solution extracted from the formulation was taken and $80 \%, 100 \%$ and $120 \%$ of pure sample solution (i.e. 16, 20 and $24 \mu \mathrm{g} / \mathrm{mL}$ ) and the $\%$ RSD was calculated.

\section{Results and Discussion}

Beer's law was obeyed in the concentration range of $1.0-60.0 \mu \mathrm{g} / \mathrm{mL}$ for both the methods A 
and $\mathrm{B}$. The linear regression equations are found to be $\mathrm{y}=-0.004 \mathrm{x}-0.001, \mathrm{y}=0.0016 \mathrm{x}-$ 0.0003 (where $\mathrm{x}$ is the concentration $(\mu \mathrm{g} / \mathrm{mL}$ ) and $\mathrm{y}$ is the absorbance derivative) with correlation coefficient 0.999 . The $\%$ RSD values in precision studies were found to be 0.3054 (Method A) and 0.8321 (Method B) which are less than $2 \%$ indicating that the method is more precise. The \%RSD values in accuracy studies were found to be 0.8192 (Method A) and 1.0253 (Method B) which are less than $2 \%$ indicating that the method is more precise.

\section{Conclusion}

The present methods can be employed for the estimation of Fluoxetine in pharmaceutical formulations successfully.

\section{Acknowledgement}

The authors are grateful to M/S Roland Institute of Pharmaceutical Sciences, Berhampur, Orissa, India for providing research facilities.

\section{References}

1. Budavari S, The Merck Index, $14^{\text {th }}$ Ed., Merck and Co. Inc., 2006.

2. Anandkumari H Prabhakar, Vandana B Patel and Rajani Giridhar, J Pharm Biomed Anal., 1999, 20(3), 427-432.

3. Ibrahim A Darwish, Sawsan M Amer Heba H Abdine and Lama I Al-Rayes., Int J Anal Chem., 2009, 10.1155/2009/257306

4. Lories I Bebawy, Naglaa El-Kousy, Jihan K Suddik and Mohamed Shokry, J Pharm Biomed Anal., 1999, 21(1), 133-142.

5. Bernard A Olsen, David D Wirth, Jacqueline S Larew, J Pharm Biomed Anal., 1998, 17(4-5), 623-630.

6. Raggi M A, Bugamelli G, Casamenti R, Mandrioli D, De Ronchi and Volterra V, $J$ Pharm Biomed Anal., 1998, 18, 699-706.

7. Mandrioli R, Pucci V, Visini D, Varani G and Raggi M A, J Pharm Biomed Anal, 2002, 29(6), 1127-1134.

8. Souverain S, Mottaz M, Cherkaoui S and Veuthey J L, Anal Bioanal Chem., 2003, 377, 880-885.

9. International Conference on Harmonisation of Technical Requirements for the Registration of Pharmaceuticals for Human Use: Validation of Analytical Procedures: Methodology, ICH Q2B, Geneva, 1996. 